\section{International Scientific Journal Theoretical \& Applied Science}

p-ISSN: 2308-4944 (print) e-ISSN: 2409-0085 (online)

Year: $2017 \quad$ Issue: $11 \quad$ Volume: 55

Published: 5.11.2017 http://T-Science.org

SECTION 6. Metallurgy and energy.
Denis Chemezov

M.Sc.Eng., Corresponding Member of International Academy of Theoretical and Applied Sciences, Lecturer of Vladimir Industrial College, Russian Federation chemezov-da@yandex.ru

Anzhelika Bayakina Lecturer of Vladimir Industrial College,

Russian Federation

bajakina.anzhelika@yandex.ru

Tatyana Lukyanova Lecturer of Vladimir Industrial College, Russian Federation

\title{
RESIDUAL STRESSES IN SILUMIN AFTER HIGH-PRESSURE DIE CASTING
}

Abstract: Submission about the solidification process of aluminum alloy after high-pressure die casting was given in the article. Intensity and distribution of residual stresses in longitudinal and transverse cross sections of a casting material after cooling are presented. It is determined that maximal stresses and strains are prevailed in casting volumes that are cooling slowly. Forecast of shrinkage, microporosity and hot tears in the casting material was given.

Key words: a casting, a field, defect, high-pressure die casting.

Language: English

Citation: Chemezov D, Bayakina A, Lukyanova T (2017) RESIDUAL STRESSES IN SILUMIN AFTER HIGH-PRESSURE DIE CASTING. ISJ Theoretical \& Applied Science, 11 (55): 1-8.

Soi: $\underline{\text { htp://s-o-i.org/1.1/TAS-11-55-1 }}$

Doi: crossef https://dx.doi.org/10.15863/TAS.2017.11.55.1

\section{Introduction}

The unique properties of aluminium alloys allow to apply these metallic materials in various industries. Aluminium parts and semi-finished products, obtained by high-pressure die casting, possess by high strength. However, this method of the castings manufacture of aluminium alloys, in particular of silumin, is characterized by less intensity of residual stresses formation in material than the other casting methods. Opinion on quality of the casting is given after execution of series of the laboratory tests (destructive and non-destructive inspection methods) by identification of defects (surface, subsurface, internal, through casting discontinuity; discrepancy of the technical conditions of the chemical composition, structure and physical and mechanical properties of the casting material; surface defects of the casting; geometry defects of the casting) $[1 ; 2 ; 3 ; 4]$. The more comprehensive analysis of the casting quality with a high degree of reliability of the results can be performed when simulation of the cooling process (solidification) of metallic melt in the mould with the identification of stressed and deformed volumes of the casting material.

\section{Materials and methods}

A numerical simulation of the process of highpressure die casting of silumin (pouring of melt into a chamber, displacement of a piston in the chamber and filling of the mould by melt, cooling of melt to complete solidification and calculation of stressstrain state of the casting material) was carried out in the computer program LVMFlow. Casting of aluminium alloy EN AC-42000 was performed on a die casting machine with a cold chamber $[5 ; 6]$. A calculated value of a volume of the casting was amount to $35397.136 \mathrm{~mm}^{3}$.

Shrinkage calculation model of the casting material (elasto-plastic stress model) included the following casting properties:

1. Compressibility is $301 / \mathrm{MBar}$;

2. CLF up is $70 \%$;

3. CLF down is $30 \%$;

4. CLFpres is $24 \%$;

5. CLF Niyama is $3 \%$.

The formation of thermophysical properties of molten silumin was carried out by phases.

Heat transfer model (air gap) included two parameters: ${ }^{\circ} \mathrm{C}$

1. Temperature of air gap formation is 516.32

2. Contact gap is $0 \mu \mathrm{m}$. 


\begin{tabular}{|c|c|c|c|c|c|c|}
\hline Impact Factor: & $\begin{array}{l}\text { ISRA (India) } \\
\text { ISI (Dubai, UAE } \\
\text { GIF (Australia) } \\
\text { JIF }\end{array}$ & $\begin{array}{l}=1.344 \\
=0.829 \\
=0.564 \\
=1.500\end{array}$ & $\begin{array}{l}\text { SIS (USA) } \\
\text { PИНЦ (Russia) } \\
\text { ESJI (KZ) } \\
\text { SJIF (Morocco) }\end{array}$ & $\begin{array}{l}=0.912 \\
=0.207 \\
=3.860 \\
=\mathbf{2 . 0 3 1}\end{array}$ & $\begin{array}{l}\text { ICV (Poland) } \\
\text { PIF (India) } \\
\text { IBI (India) }\end{array}$ & $\begin{array}{l}=6.630 \\
=1.940 \\
=4.260\end{array}$ \\
\hline
\end{tabular}

The three-dimensional model of the casting in longitudinal and transverse cross sections is

presented in Fig. 1.

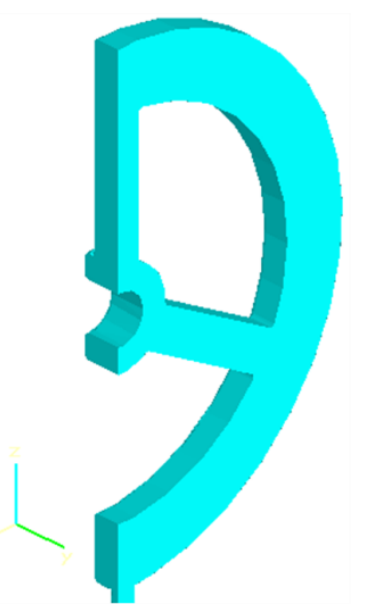

Figure 1 - Model of the casting.

Total emissivity of the mould was adopted 0.93 , gas permeability was adopted $1.53 \times 10^{-6} \mathrm{~m}^{2} / \mathrm{Pa} \times \mathrm{s}$. High rigidity of the mould provided minimum deviations of dimensions and geometric shape of the casting. Radiolucency of air in the channels of the mould was adopted 1 . Temperature of the mould and air before performing of the casting process of aluminium alloy was adopted $20{ }^{\circ} \mathrm{C}$. Silumin solidification in the mould was performed on the basis of solidification factor, which was adopted 3.8 [7].

\section{Results and discussion}

Calculated maximum and minimum values of some parameters of the technological process of high-pressure die casting are presented in table 1.

Table 1

Maximum and minimum values of some parameters of the technological process of high-pressure die casting.

\begin{tabular}{|c|c|c|}
\hline Parameter & $\begin{array}{c}\text { Maximum } \\
\text { value }\end{array}$ & $\begin{array}{c}\text { Minimum } \\
\text { value }\end{array}$ \\
\hline Liquid phase, $\%$ & 0 & 0 \\
\hline Local solidification time, $\mathrm{s}$ & 1.752 & 0 \\
\hline Solidification time, $\mathrm{s}$ & 2.159 & 0 \\
\hline $\mathrm{dT} / \mathrm{dt},{ }^{\circ} \mathrm{C} / \mathrm{s}$ & -18.767 & -379.128 \\
\hline Fill time, $\mathrm{s}$ & 0.332 & 0.313 \\
\hline Wall contact time, $\mathrm{s}$ & 2.197 & 0 \\
\hline Air contact time, $\mathrm{s}$ & 0.31 & 0 \\
\hline Solid phase, $\%$ & 100 & 71.866 \\
\hline
\end{tabular}

The field of melt velocities before cooling in the mould is presented in Fig. 2.

Analysis of the velocities field shows that the maximum velocity of melt before crystallization is $3.7 \mathrm{~m} / \mathrm{s}$. As far as filling of the mould by melt, its velocity is reduced to $0.5 \mathrm{~m} / \mathrm{s}$ in the most remote from the feeder of the local volumes of the casting. Since the casting is positioned vertically in the mould, and an inlet of melt occurs under high pressure bottom-up, then a lower part and connecting elements of the casting is cooled more slowly.

The field of pressure is presented in Fig. 3.

Pressure of melt in the mould is almost constant, as the inlet of material is implemented at the constant velocity of displacement of the piston (an injection phase). Negative pressure was defined on the inner surface of the mould and is the result of formation in this area of turbulent flows of melt.

The field of thermal modulus of the casting after solidification is presented in Fig. 4.

Analysis of this field shows that the overall dimensions of the feeder were calculated optimally. Recalculation of the dimensions of the feeder is not required as the value of thermal modulus on the entire volume of the casting virtually is not changed.

Shrinkage of the casting material after solidification is presented on the corresponding field (Fig. 5).

In the analysis of the field of material shrinkage, it can be concluded that the inner layers of the casting are exposed to larger linear shrinkage $(10 \ldots 30 \%)$ than outer layers (up to $3 \%$ ). This is the 
permissible value of linear shrinkage for the casting having made by high-pressure die casting.

Intensity of microporosity formation in the casting material after solidification is presented in Fig. 6.

The critical value of the Niyama criterion during high-pressure die casting of silumin on the die casting machines with the cold chamber is equal to 0.8 . Below this value probability of microporosity formation is increased. The forecast of microporosity formation almost coincides with the forecast of linear shrinkage formation of the casting material.

The field of displacement of the casting after solidification (relatively of the mould) is presented in Fig. 7.

By this field it can give an assessment of direction and value of displacement of the casting surfaces in the mould during shrinkage. These displacements amount to about $0.05 \ldots 0.48 \mathrm{~mm}$. Average values of displacements is $0.25 \mathrm{~mm}$.

The field of maximal principal stress of the casting material after solidification is presented in Fig. 8.

After solidification of material practically the entire volume of the casting is exposed to positive principal stress (tensile). In coupling sites of three elements of the casting there are observed the local volumes exposed to compression (negative values of stress). The maximum value of principal stress of the casting material does not exceed $80 \mathrm{MPa}$. It does not cause significant defects.

The field of von Mises stress of the casting material after solidification is presented in Fig. 9.

A significant shear of layers of the casting volume, having made by high-pressure die casting, observed also in coupling sites of three elements. It is in these places of the casting probability of occurrence of the casting defects is large.
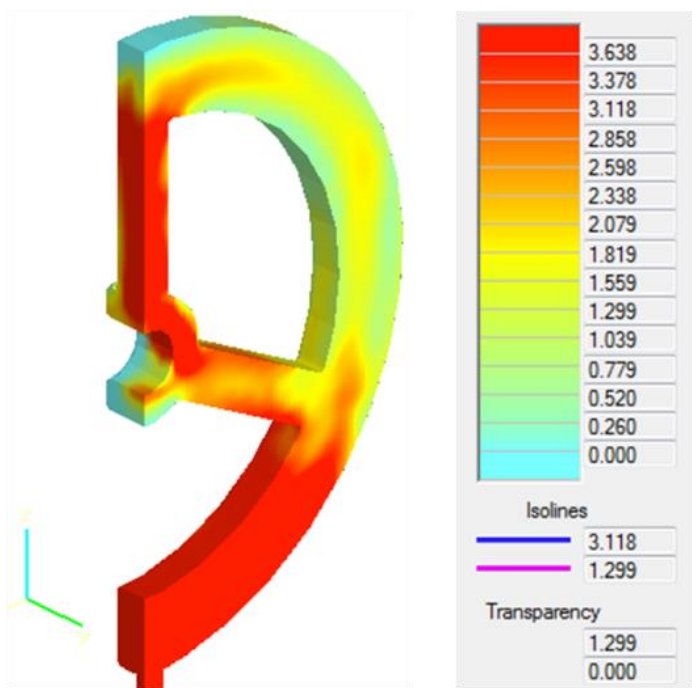

Figure 2 - The field of melt velocities. Unit of measurement is $\mathrm{m} / \mathrm{s}$.
The field of pressure of the casting material after solidification is presented in Fig. 10.

In this field of pressure of material confirms the fact that compressive stresses are occurred in the more rapidly cooling parts of the casting, and tensile stresses are occurred in the more slowly cooling parts of the casting.

The field of effective plastic strain of the casting material after solidification is presented in Fig. 11.

Effective plastic strain of material after solidification almost uniformly distributed on the entire volume of the casting. The small value of the coefficient of effective plastic strain says about minimal change of the geometric shape of the casting after solidification.

The field of plastic deforming work of the casting material after solidification is presented in Fig. 12.

Compare this field with the field of effective plastic strain of material shows that plastic strains arise in the areas of stresses work in plastic deforming of the casting volumes. For the accepted conditions of high-pressure die casting the value of plastic deforming work of the casting material does not exceed $1 \mathrm{MPa}$.

The formation of hot tears during solidification of the casting is presented in Fig. 13.

The formation of hot tears in the casting material occurs at the end of the time range of the crystallization process. The calculated coefficient of prediction of hot tears in silumin does not exceed 0.5 , which is approximately in 5 times less than intensity of the formation of hot tears during casting of carbon steels. The solidification process of the casting volume is uniformly with the exception of $2-3 \%$ of the material volume on the formation of hot tears. 


\begin{tabular}{l|lrl|l|ll} 
& ISRA (India) & $=\mathbf{1 . 3 4 4}$ & SIS (USA) & $=\mathbf{0 . 9 1 2}$ & ICV (Poland) & $=\mathbf{6 . 6 3 0}$ \\
Impact Factor: & ISI (Dubai, UAE) $=\mathbf{0 . 8 2 9}$ & PUHU (Russia) $=\mathbf{0 . 2 0 7}$ & PIF (India) & $=\mathbf{1 . 9 4 0}$ \\
& GIF (Australia) & $\mathbf{0 . 5 6 4}$ & ESJI (KZ) & $=\mathbf{3 . 8 6 0}$ & IBI (India) & $\mathbf{4 . 2 6 0}$
\end{tabular}
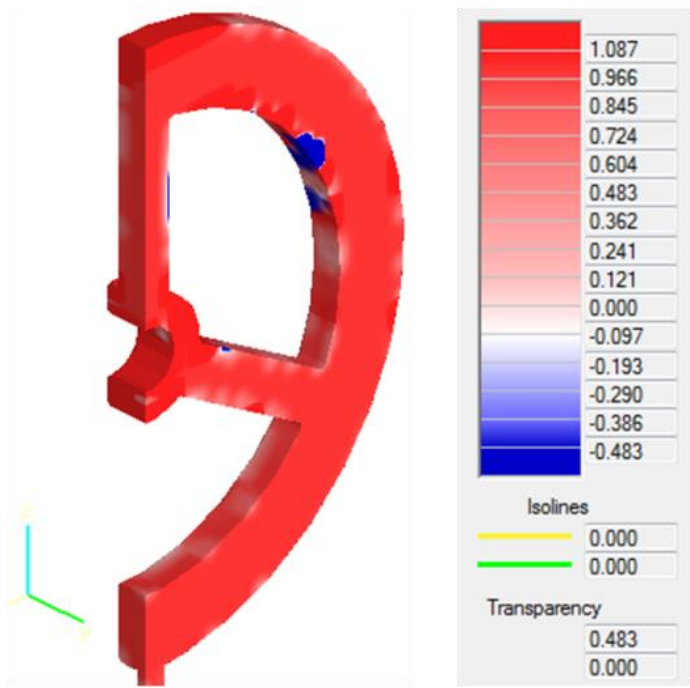

Figure 3 - The field of pressure. Unit of measurement is Bar.
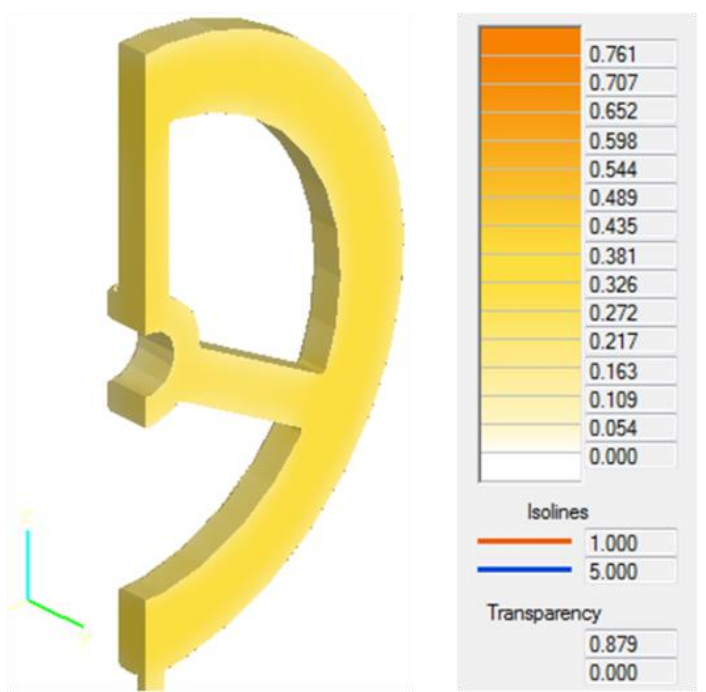

Figure 4 - The field of thermal modulus of the casting. Unit of measurement is $\mathbf{c m}$.
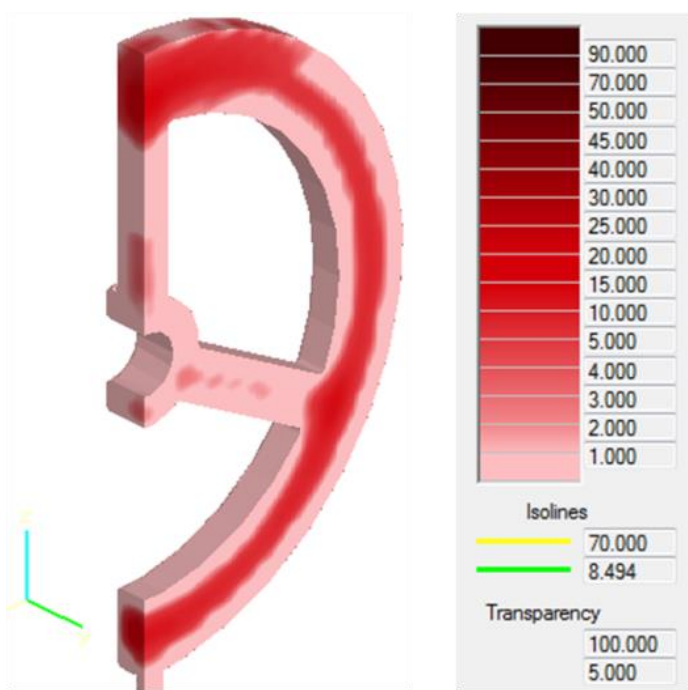

Figure 5 - The field of shrinkage of the casting. Unit of measurement is \%. 


\begin{tabular}{l|lrl|l|ll} 
& ISRA (India) & $=\mathbf{1 . 3 4 4}$ & SIS (USA) & $=\mathbf{0 . 9 1 2}$ & ICV (Poland) & $=\mathbf{6 . 6 3 0}$ \\
Impact Factor: & ISI (Dubai, UAE) $=\mathbf{0 . 8 2 9}$ & PUHU (Russia) $=\mathbf{0 . 2 0 7}$ & PIF (India) & $=\mathbf{1 . 9 4 0}$ \\
& GIF (Australia) & $\mathbf{0 . 5 6 4}$ & ESJI (KZ) & $=\mathbf{3 . 8 6 0}$ & IBI (India) & $\mathbf{4 . 2 6 0}$
\end{tabular}

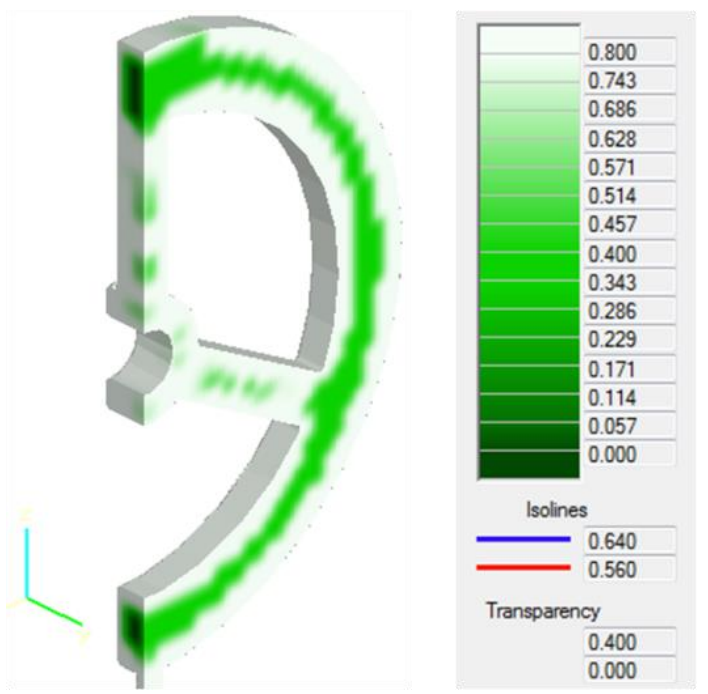

Figure 6 - The field of the Niyama criterion. Unit of measurement is $\frac{\sqrt{{ }^{\circ} \mathrm{K} \times s}}{\mathrm{~mm}}$.
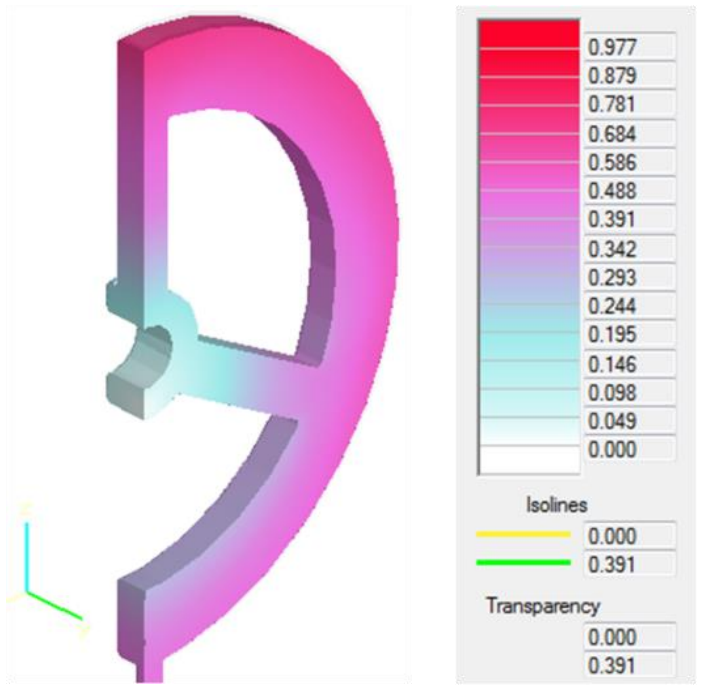

Figure 7 - The field of displacement of the casting. Unit of measurement is $\mathbf{m m}$.

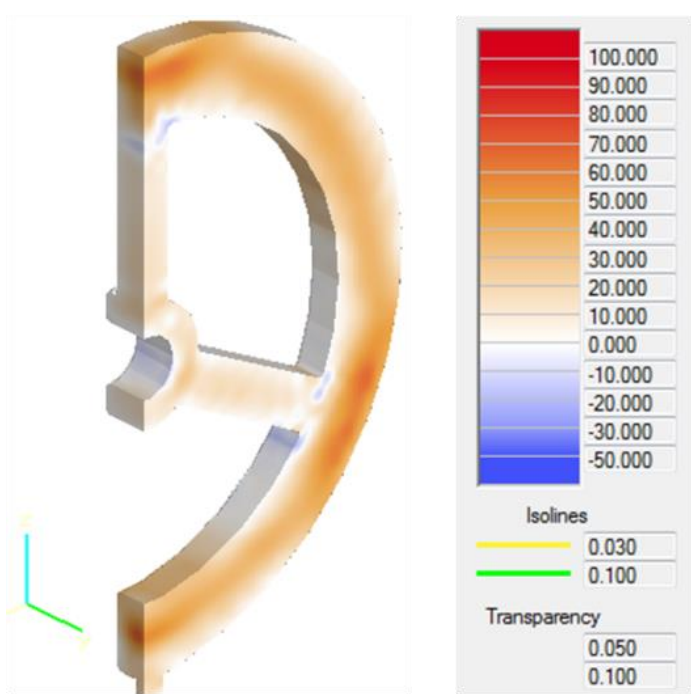

Figure 8 - The field of maximal principal stress of the casting material. Unit of measurement is MPa. 


\begin{tabular}{l|lrl|l|ll} 
& ISRA (India) & $=\mathbf{1 . 3 4 4}$ & SIS (USA) & $=\mathbf{0 . 9 1 2}$ & ICV (Poland) & $=\mathbf{6 . 6 3 0}$ \\
Impact Factor: & ISI (Dubai, UAE) $=\mathbf{0 . 8 2 9}$ & PUHU (Russia) $=\mathbf{0 . 2 0 7}$ & PIF (India) & $=\mathbf{1 . 9 4 0}$ \\
& GIF (Australia) & $\mathbf{0 . 5 6 4}$ & ESJI (KZ) & $=\mathbf{3 . 8 6 0}$ & IBI (India) & $\mathbf{4 . 2 6 0}$
\end{tabular}
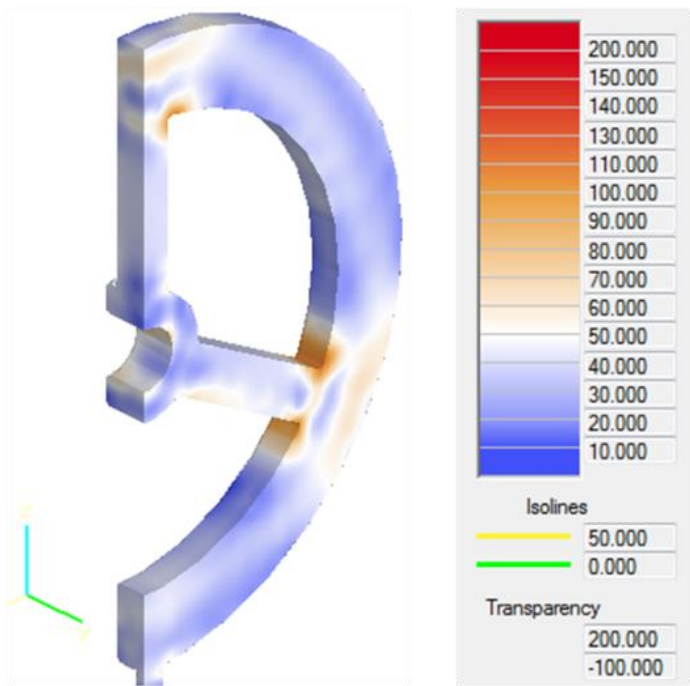

Figure 9 - The field of von Mises stress of the casting material. Unit of measurement is MPa.

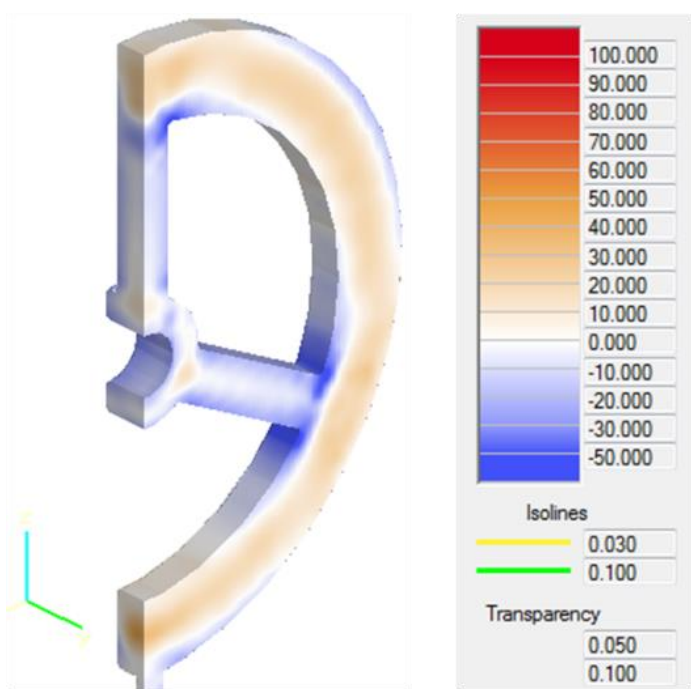

Figure 10 - The field of pressure of the casting material. Unit of measurement is MPa.

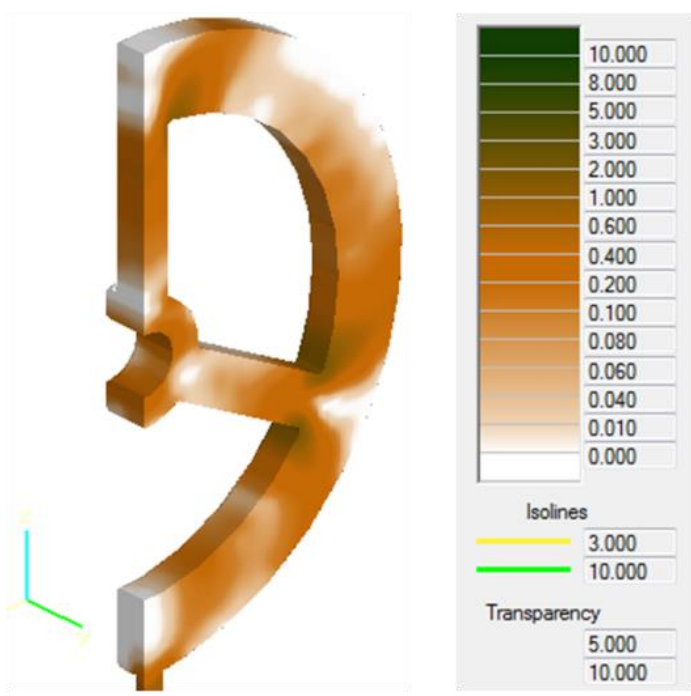

Figure 11 - The field of effective plastic strain of the casting material. Unit of measurement is $* 0.01$. 


\begin{tabular}{l|lr|ll|ll} 
& ISRA (India) & $\mathbf{1 . 3 4 4}$ & SIS (USA) & $=\mathbf{0 . 9 1 2}$ & ICV (Poland) & $=\mathbf{6 . 6 3 0}$ \\
Impact Factor: & ISI (Dubai, UAE) $=\mathbf{0 . 8 2 9}$ & PUHI (Russia) & $=\mathbf{0 . 2 0 7}$ & PIF (India) & $=\mathbf{1 . 9 4 0}$ \\
& GIF (Australia) & $=\mathbf{0 . 5 6 4}$ & ESJI (KZ) & $=\mathbf{3 . 8 6 0}$ & IBI (India) & $\mathbf{4 . 2 6 0}$ \\
& JIF & $\mathbf{1 . 5 0 0}$ & SJIF (Morocco) & $\mathbf{2 . 0 3 1}$ & & \\
\hline
\end{tabular}
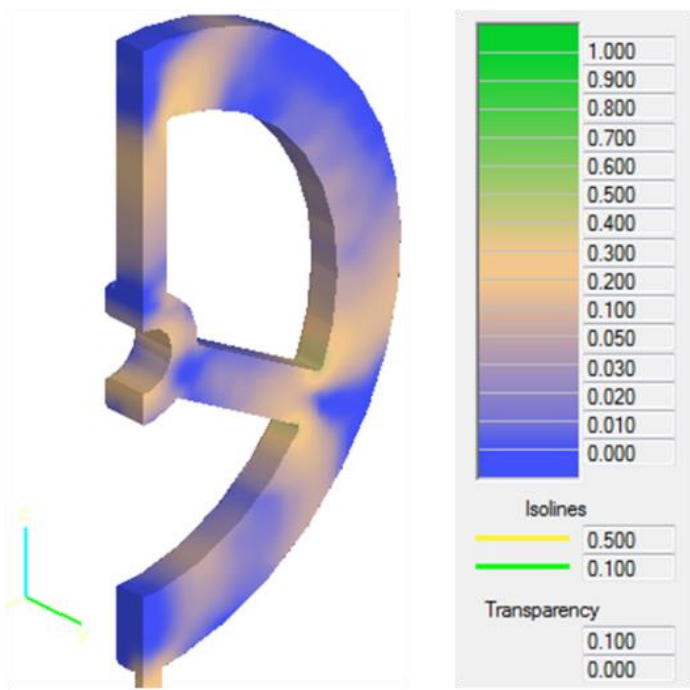

Figure 12 - The field of plastic deforming work of the casting material. Unit of measurement is MPa.
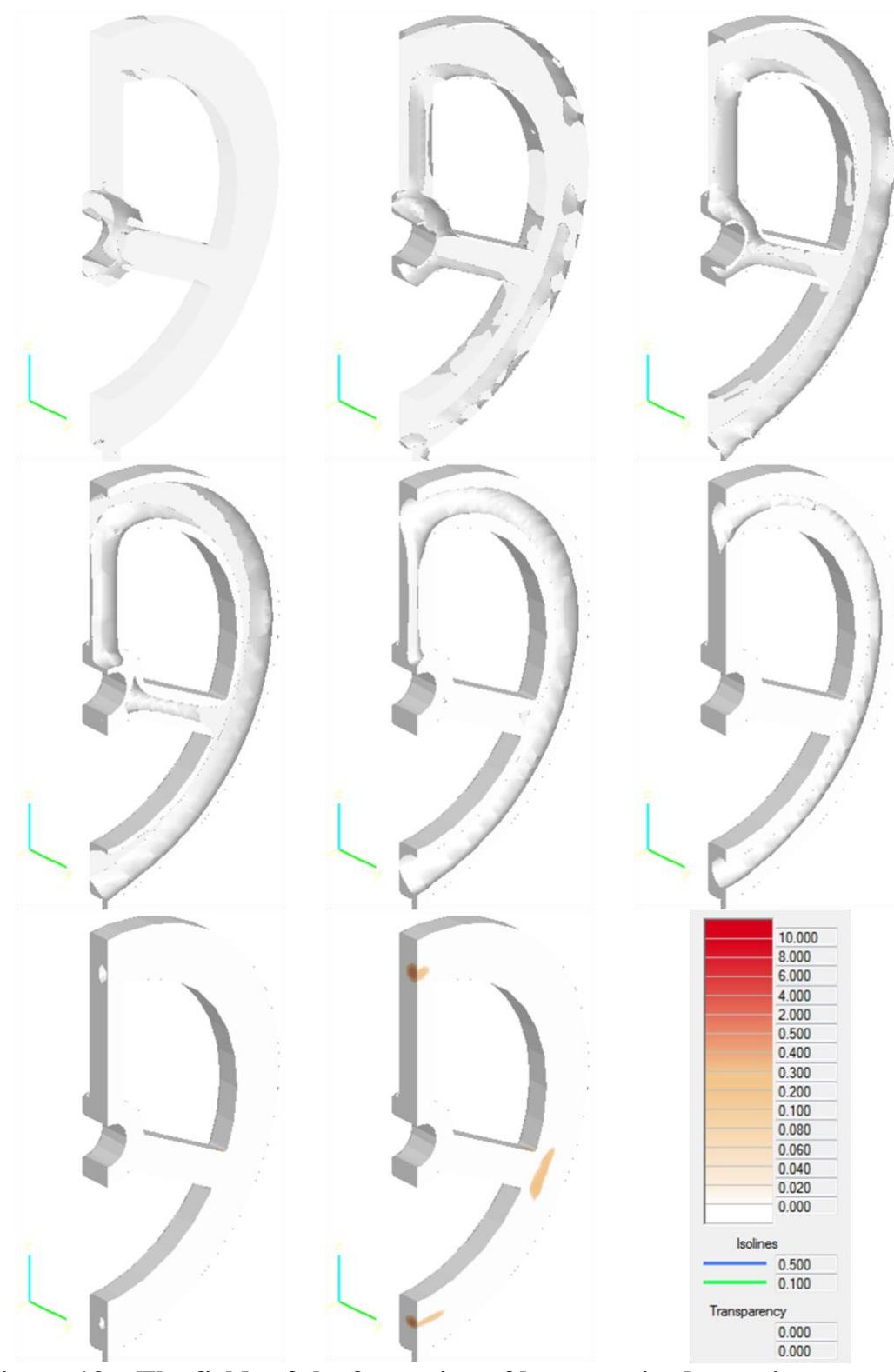

Figure 13 - The fields of the formation of hot tears in the casting material. 


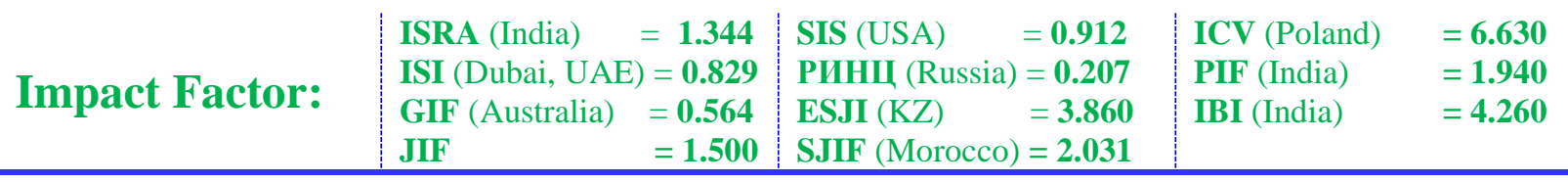

\section{Conclusion}

Thus, it may be concluded that the highest residual stresses of material occur in coupling sites and abrupt change of the cross section of the casting. Linear shrinkage of the casting after solidification can reach $30 \%$, but minimal intensity of the formation of hot tears in the inner layers of material says about acceptable quality of the casting structure in accordance with normative legal documents.

\section{References:}

1. (1993) GOST 1583-93. Aluminium casting alloys. Specifications.

2. (1971) GOST 1762.0-71. Aluminium-silicon alloy ingots. General requirements for methods of analysis.

3. (1981) GOST 7727-81. Aluminium alloys. Methods of spectral analysis.

4. (1980) GOST 24231-80. Non-ferrous metals and alloys. General requirements for sampling and sample preparation for chemical analysis.

5. Chemezov D (2017) Simulation of the technological process of high-pressure die casting of silumin. ISJ Theoretical \& Applied
Science, 10 (54): 1-4. Soi: http://s-0i.org/1.1/TAS-10-54-1 Doi: https://dx.doi.org/10.15863/TAS.2017.10.54.1

6. Chemezov D (2017) Movement of metallic melt in a cold chamber of a die casting machine. ISJ Theoretical \& Applied Science, 10 (54): 109113. Soi: http://s-o-i.org/1.1/TAS-10-54-22 Doi:

https://dx.doi.org/10.15863/TAS.2017.10.54.22

7. Prikhod'ko OG, Selyanin IF, Kutsenko AI (2004) Calculation of time and rate of solidification of castings in metallic form. Polzunovskii almanac, №4. - pp. $18-20$. 